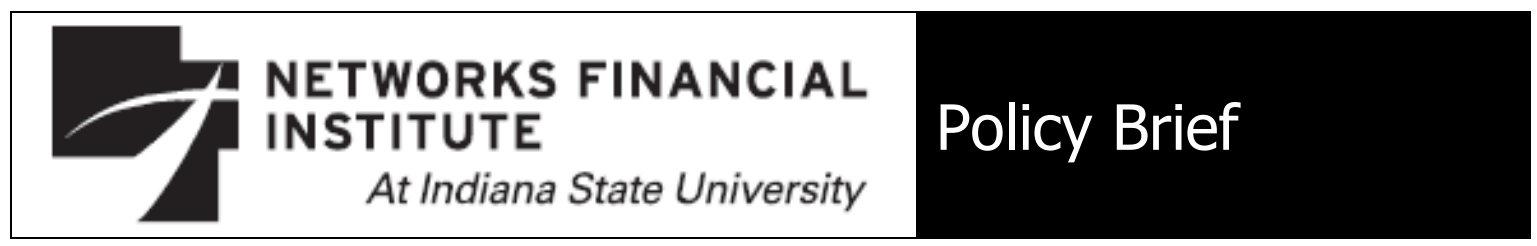

2010-PB-05

August 2010

\title{
Financial Legislation: The Promise and Record of the Financial Modernization Act of 1999 \\ John A. Tatom
}

Abstract: On November 12, 1999, President Clinton signed the most significant piece of financial services regulation to be enacted since the Great Depression, at least up to that time. When the Financial Service Modernization Act of 1999, better known as the Gramm-Leach-Bliley Act (GLBA), was signed, the financial services industry faced strong pressures for deregulation of the rigid structure imposed during the Great Depression. During the 2007-08 financial crises and ensuing debate regarding financial services regulation, the GLBA became a target as members of the financial sector, academia and government considered possible triggers that may have precipitated the crisis.

About the Author: John A. Tatom is the Director of Research at Networks Financial Institute at Indiana State University and Associate Professor of Finance at Indiana State University. He has published widely on international and domestic monetary and fiscal policy issues, especially inflation, capital formation, productivity and growth; the macroeconomics of supply, especially oil and energy price shocks; the relationship of exchange rate movements to international competitiveness, capital flows, trade, and international economic policy; and on financial innovations and their effects on monetary policy and the economy, among other areas.

Keywords: Glass-Steagall Act, Dodd-Frank Act, financial regulation, financial crisis.

JEL Classifications: G18, K20 and E50.

The views expressed are those of the individual author and do not necessarily reflect official positions of Networks Financial Institute. Please address questions regarding content to Chris Whalen at chris@cwhalen.com. Any errors or omissions are the responsibility of the author. NFI policy briefs and other publications are available on NFI's website (www.networksfinancialinstitute.org). Click "Thought Leadership" and then "Publications/Papers." 


\section{Financial Legislation: The Promise and Record of the Financial Modernization Act of 1999}

\section{John A. Tatom}

On November 12, 1999, President Clinton signed the most significant piece of financial services regulation to be enacted since the Great Depression, at least up to that time. When the Financial Service Modernization Act of 1999, better known as the GrammLeach-Bliley Act (GLBA), was signed, the financial services industry faced strong pressures for deregulation of the rigid structure imposed during the Great Depression. During the 2007-08 financial crises and ensuing debate regarding financial services regulation, the GLBA became a target as members of the financial sector, academia and government considered possible triggers that may have precipitated the crisis.

The dramatic events that shook the U.S. financial services sector in 2008, including the deployment of the Troubled Asset Relief Program (TARP) and the failures of some of the nation's largest financial firms, made financial services regulation a heated topic on the national policy agenda. In June 2009, the Obama Administration set forth a new proposal for financial services regulation [see U.S. Treasury (2009)] and the Congress completed action on the reforms in July 2010 in the Wall Street Reform and Consumer Protection Act of 2010, or Dodd-Frank, signed into law on July 21, 2010. While the effects of the new legislation are still uncertain, some lessons about the role of legislation and its implications can be gleaned from reviewing the experience with the GLBA and the recent crisis. Most of the provisions of Dodd-Frank require studies or new regulatory specifics from regulatory authorities, an estimated 500 of them in total. Thus, until those new regulations are fleshed out, it is difficult to assess the effects of the Act except to assert that it is the largest intrusion of federal regulatory authority since the Glass-Steagall Acts of 1933 and 1935. ${ }^{1}$ This paper reviews the contribution of the GLBA, its critics and its effects on the 2007-08 financial crisis and the new Dodd-Frank legislation.

\section{Why Regulate Banks and Other Financial Institutions}

After the foreclosure and financial crisis of 2007-09, it may seem strange to ask why political leaders might want to regulate banks or other financial institutions. But this question does not have an answer that is as obvious as it may seem. There are three main reasons that have been put forward as justifications for financial regulation. The first is asymmetric information, that is, that corporations have unequal access to private information that belongs to stockholders and this information is necessary for sound private decision-making by stockholders and other investors. Regulations aim to avoid market failures that would occur if valuable information, which is essentially free or relatively inexpensive, but otherwise private, is not provided to markets; such a failure

\footnotetext{
${ }^{1}$ Developing and promulgating new regulations dictated by Dodd-Frank is not the only obstacle. Most of the issues presented by the financial crisis are unaddressed or not fully addressed by Dodd-Frank so at least another major round in regulatory reform can be expected in the next few years in the United States. These include a large number of issues raised about fixing too-big-to-fail and how to repair critical holes in the regulation of complex financial institutions, retirement saving and credit default swaps and other new and complex instruments, where thoughtful proposals have been developed by the Squam Lake group. See French et al (2006).
} 
would reduce capital formation and the size of the corporate sector. This is the main justification for the regulatory authority of the Securities and Exchange Commission, which was founded in 1934. This explanation leads to informational reporting requirements for corporations and disclosure of key financial information that might not exist, or might not be uniform, otherwise. Note that this does not lead to a special case for regulation of banks or financial institutions, only all corporations. ${ }^{2}$ Some financial economists and analysts, however, believe that these issues are more significant for banks and other financial institutions. VanHoose (2010) reviews theories of bank regulation and concludes that there is no compelling case for "market failure" to warrant a case for bank regulation. Market failures arising from large external spillovers, significant market power or so-called informational asymmetries are not found in the empirical literature on banking.

The second rationale is regulatory capture, where efforts by industry incumbents to use legislation and political authority to secure competitive advantages lead to industry regulation. In this theory, banking firms demand and use state regulation as a means to protect themselves from competitive entry. VanHoose (2010) concludes that this alternative theory better explains patterns of bank regulation than the asymmetric information theory.

Another rationale for financial regulation is that fractional reserve banking, the fact that banks hold cash assets that are a fraction of their liabilities, many of which are payable on demand, gives rise to an inherent risk of runs on banks that can lead to failure of otherwise solvent banking institutions. Because of this, legislation providing for government insurance of bank deposits was adopted in 1933 to create the Federal Deposit Insurance Corporation (FDIC). Not surprisingly, this action led to a further justification for bank regulation to ensure solvency of banks in order to minimize taxpayer exposure to losses of the FDIC should industry paid premiums be insufficient, as, for example, in a financial crisis. Such a rationale has led to regulations aimed at limiting competition, such as limits on interest rates paid by banks, entry regulation to protect profit, and a variety of requirements on asset composition and other operational decisions in order to protect bank profitability and avoid losses and insolvency. This rationale has been extended, without serious examination or evidence, to all financial institutions, not just banks, by the Federal Reserve (Fed) and the U.S. Treasury, with tacit endorsement by the Congress, to encompass the notion that financial institutions can be "too interconnected," so that shocks in some part of the industry can lead to failures elsewhere. This may appear to be similar to the "bank runs" problem, but it is not. There is no end to the potential for losses due to interconnectedness, whether in banking, the rest of the financial industry or even non-financial business, because all consumers and producers are connected to varying degrees to others consumers and producers.

\footnotetext{
${ }^{2}$ Barth, Caprio and Levine (2006), based on a data set of 150 countries, conclude that regulation based upon disclosure and market-based monitoring provide superior outcomes based on a broad range of desirable regulatory outcomes. Regulations employing entry restrictions, government ownership or restrictions on banking activities, such as those arising from regulatory capture adversely affect banking system performance.
} 
VanHoose (2010) points out that another rationale for financial regulation, consumer protection, is inadequate. He quotes Benston (2000), who wrote that "most nations already have broad social regulations to address such issues." 3 This rationale was an important component of the GLBA and more recently of Dodd-Frank. VanHoose cites studies that show that the cost of bank regulation is substantial relative to overall bank expenses; these estimates are striking given the popular notion that deregulation since the 1970s has reduced regulatory costs to negligible levels.

\section{Looking Back at The GLBA - Great Expectations and Some Skepticism}

The Glass-Steagall Act of 1933, which created the FDIC and other significant banking reforms, contained provisions that prohibited a bank holding company from owning other financial companies. The GLBA repealed these legal separations, allowing bank holding companies to own insurance, financial planning/investment firms and other financial service businesses. The "financial holding company" structure allowed banks, securities firms and insurance companies to offer each other's products. For example, a bank could create a financial services holding company to offer insurance or security services; and an insurance company could provide retail or investment banking services. Essentially, the GLBA broke down the barriers to competition across the financial services portfolio.

The authors of the GLBA expected that the Act would enhance competition between firms and allow financial services to be provided more efficiently through a streamlined enterprise. The emergence of electronic and Internet-based banking services largely negated many of the barriers that had served to make banking a geographic-based delivery system in the past, even without the GLBA. By providing consumers with a "one stop shop" where they could take care of all of their financial business, the GLBA was intended to optimize consumer convenience. Under the GLBA, banks, insurance companies, security companies and investment banks could offer their customers products and services beyond their traditional product portfolios. Besides, enhanced competition and efficiency, many thought that the GLBA would open the doors for more product innovation. The reasoning was that if bank holding companies were able to offer a broader menu of products, they would be inclined to develop new products that would meet customers' evolving needs while generating additional revenue for the bank.

The primary innovations that arose from the GLBA were changes in how products were distributed as opposed to the development of new products. Under the Act, retail banks, investment banks, insurance companies and securities firms, were able to leverage economies of scope and scale to distribute traditional products from other sectors to better serve the portfolio of financial needs of their customers. This increased competition in distribution resulted in lower profit margins but also provided new profit centers in each sector of the industry. For example, while community banks increased marketing of insurance products and security services, they tended to secure these services from external sources as opposed to developing the services in-house. This arrangement resulted in security and insurance companies enjoying a sales boost as other institutions promoted their products. Money center and super regional banks benefited

\footnotetext{
${ }^{3}$ See VanHoose (2010), p. 198.
} 
from the ease of expanded sales of both variable and fixed annuities and development of their own security products.

The GLBA allowed banks to develop private equity businesses that could hold investments for up to ten years, allowing banks to provide equity financing to small and medium-sized firms. Additionally, the Act made it easier for banks of all sizes to underwrite municipal securities and develop securities sales and origination services, as well as insurance products. Likewise, insurance companies used the GLBA to cultivate new revenue streams. Met Life became one of the largest financial holding companies. Allstate Insurance's interstate bank emerged as a truly national competitor in retail banking services by using its agent network to cross-sell banking services.

The ability to provide bank financing to investment banks' corporate clients was an attractive service for large corporations which increased competition for investment banking services. However, not all investment banks actually became part of financial holding companies with banking affiliates. This changed after the financial crisis arose. Following the failure of Bear Stearns and Lehman Brothers, two investment banks without significant attachments to bank affiliates, Goldman Sachs and Morgan Stanley became bank holding companies. Today there is no major investment bank that exists outside of a financial holding company structure. As the credit crisis continued, commercial bank charters offered the attractive benefit of immediate access to liquid funds through the Federal Reserve. The GLBA made possible the bank mergers that quickly and efficiently resolved two of the largest institutional failures in the financial crisis, Bear Stearns and Merrill Lynch.

A key financial innovation brought about by the financial integration permitted by the GLBA was reduced systematic risk. ${ }^{4}$ Stock prices rose for banks, insurance companies and security firms on the passage of the GLBA. Bank stocks, especially money center and super regional bank stocks, gained the most, followed by insurance companies and then security firms. Meanwhile, overseas insurers' stock prices dropped significantly. Evidence shows that part of the gain in rates of return on stocks was due to lower systematic risk premiums associated with these firms.

As with most new legislation, the GLBA was not accepted warmly by all portions of the industry. One of the primary concerns in the drafting and eventual passage of the GLBA was the protection of customer privacy. Critics questioned whether the vast amount of information held by one institution would compromise the privacy of account holders. Extensive restrictions on intra- and inter-company sharing of customer information were included in the Act to address these concerns.

Another criticism was that the GLBA was enacted to formalize a fait accompli - the merger of Citibank and Travelers Group to create Citigroup, announced in 1998. However, this was not true. The merger of Travelers Group and Citicorp was approved by the Fed on the basis that "non-permitted businesses would be divested within a pre-

\footnotetext{
${ }^{4}$ See Hassan, Mamun and Isik, Chapter 4 below, and Hassan and Mamun, Chapter 5 below, as well as their references to other studies.
} 
defined time frame." The passage of the GLBA eased the burden of an agreement that had already been negotiated and eliminated the concerns about the cost or difficulties of complying with the divesture requirements.

A third concern was that the GLBA would enable large mega-institutions to dominate commercial banking, investment banking, brokerage and insurance business. By creating "superstore" banks, some feared that smaller institutions including community banks would not be able to compete.

\section{Did The GLBA Achieve its Intentions?}

Interestingly, many of the outcomes of the GLBA did not play out as both authors and critics thought they might. The GLBA did not result in a rush of financial services firms delving into new lines of business, except among the largest institutions. Beyond notable mergers (e.g. Citigroup and Travelers, JP Morgan and Chase) the industries' response was primarily in the sale of nontraditional products, rather than the "manufacturing" of new products. As of June 29, 2009, there were only 592 financial holding companies authorized by the Federal Reserve, and most of them were small and had limited availability of nontraditional products.

The GLBA seems to have been more effective at fostering product delivery than creating new types of products. Around the same time that the GLBA was being introduced, new technology was providing the financial services industry with sophisticated tools such as marketing customer information files (MCIF) and data warehousing programs. These tools made it easy for marketers to categorize customers by life-stage and create bundles of products tailored to life-stages or product usage. For example, a customer with an auto loan would be a prime candidate to cross-sell an insurance policy to; a senior club member might be interested in a money market or other high-yield deposit account.

To some extent, primarily through acquisition, holding companies were formed to allow broader menus of products to be manufactured in house. However, over time, many institutions have opted to source specific financial products from specialists, focusing on the distribution of products in response to consumer needs.

Skeptics' concerns about privacy have also not borne out. The newly-formed Citigroup led the way in crafting privacy restrictions that are included in the GLBA. The three principal parts to the privacy requirements of the GLBA include the Financial Privacy Rule, Safeguards Rule and pretexting provisions. The language and restrictions within each section of the Act's privacy components seem to have served their purpose in protecting customer information from wide dissemination across subsidiaries.

\section{The GLBA and the Financial Crisis}

As the financial crisis emerged, debate arose regarding any role that the Act may have played in creating products that were not by definition innovative, but rather, controversial, or other changes that may have contributed to the crisis. Some questioned 
whether the innovation that the GLBA fostered had included financial products linked to the subprime crisis - specifically mortgage loans and the array of new investment products created during the housing bubble. It must be noted that rapid growth in home buying and thus the growth in mortgage assets was a result of public policy pressures to increase homeownership in the U.S. The resulting growth of mortgage companies, especially some tied to real estate companies and to thrift institutions, led to substantial changes in the processing of mortgage applications and to new channels of financing at increasingly competitive prices. This trend was reinforced by banks' movement away from the "originate and hold" model to an "originate and distribute" model. Under the new model, banks made and serviced mortgage loans, but sold the loans to investment banks and government sponsored entities (GSEs) Fannie Mae and Freddie Mac, who in turn packaged the loans into pools against which they issued securitized mortgages. These purchasers, especially some investment banks, went one or more steps further, pooling these securities to create collateralized debt obligations and even more esoteric versions of these instruments. The initial mortgage securitization instruments and process were not new, however; they had existed for 15 to 20 years. What was new and especially problematical was including risky subprime mortgages and especially adjustable rate subprime mortgages, in these packages. Adjustable rate subprime loans grew rapidly in 2004-2007 just as market interest rates were rising, so that earlier loans of this type were resetting to, in many cases, unaffordable levels.

These new products were the creation of investment banks that could have developed them with or without the GLBA. And they were part of a pattern of new instruments developed there that failed when a more normal appetite for credit risk returned to markets in 2007 and subsequently. The illiquidity of instruments like auction rate securities, structured finance products was stunning following the rapid growth of such new products during the previous few years as investors abandoned caution in search of yield on their investments in what was essentially a very low rate of return environment. Riskier and higher yielding new assets became the rage.

Even though none of these new instruments could be linked to the GLBA, some critics were quick to blame the law for the financial crisis. Nobel Laureate Paul Krugman lays blame on Senator Gramm, the lead author of the GLBA, and on the GLBA noting: "Aha: the Politico notices that Phil Gramm, McCain's presidential economic guru, can also be viewed as the father of the financial crisis." 5 Nobel Prize-winning economist Joseph Stiglitz called for the repeal of the GLBA in the January 2009 issue of Vanity Fair. While political opposition to the GLBA exists, no political leader stepped forward to champion, repeal or revision of the GLBA. President Barak Obama, while a presidential candidate in 2008, expressed the view that the GLBA was responsible for the mortgage crisis, but neither he nor congressional leaders followed up with the repeal of the GLBA. ${ }^{6}$ Henry Kaufman argues that the GLBA caused the crisis and advocates a return to a narrow bank regime in line with the Glass-Steagall regulatory structure. ${ }^{7}$ Paul Volcker has also

\footnotetext{
${ }^{5}$ See Krugman (2009).

${ }^{6}$ See Paletta and Scannell (2009).

${ }^{7}$ See Kaufman (2010).
} 
expressed regret over the passage of the GLBA and the failure of Dodd-Frank to repeal it. $^{8}$

One could argue that the partial adoption of the Volcker Rule, which would have prohibited banks from conducting private equity, hedge fund or proprietary trading businesses, in Dodd-Frank reflected a repeal of the most dangerous elements of the GLBA. This would be wrong, however, for at least two reasons. First, Volcker did not regard his original proposal as repealing the GLBA, ${ }^{9}$ and second, Dodd-Frank did not implement the Volcker Rule. Instead it put limits on the extent of two of these businesses, with private equity and hedge fund assets limited to no more than 3 percent of total assets, required these activities to be conducted in separate subsidiaries, and eliminated proprietary trading activities of banks. The latter is hard to define and is likely to prove difficult to eliminate since similar activities are routinely conducted in other traditional parts of the asset management of banks. Its effectiveness will be determined, as so much of Dodd-Frank, by regulators' new processes to enforce it.

Opposition to the GLBA appears to be more advanced in Britain, where the Tory leadership is advocating adoption of a Glass-Steagall type separation of banking from financial services. This is unique in that the British financial system has not had such a separation structure in the past. George Osborne, new Chancellor of the Exchequer, advocated this approach when he was shadow Chancellor, as did the former Tory Chancellor, Nigel Lawson, who noted "Capitalism needs a revived Glass-Steagall Act."10 Nonetheless, when the Tories came to power in June 2010, adoption of a policy like Glass Steagall was not part of the program.

The mortgage crisis arose because of the growth of subprime mortgage products developed by mortgage bankers and investment banks, most of them unregulated, and whose products were certainly not under the auspices of the GLBA provisions that govern bank holding companies or of other commercial banking laws. Significant pressure from Congress, supported by mandates and federal subsidies to foster homeownership helped accelerate the growth and development of subprime products.

As a result of the growth in home ownership and specifically the growth of subprime mortgage assets, incentives were created for investment banks to develop financial products to leverage and manage their mortgage portfolios. These products were often created by nontraditional companies and thus, marketed outside of traditional regulatory structures. These new products included subprime-based mortgage backed securities, collateralized debt obligations, collateralized loan obligations, auction rate securities and credit default swaps. While some of these products were sound, many were complex and unknown, creating a misunderstood risk profile.

\footnotetext{
${ }^{8}$ See Uchitelle (2010). Volcker has argued elsewhere that financial deregulation introduced no new innovations beyond the automatic teller machine, but in this article cites derivatives, securitizations and credit default swaps as products that did not exist before deregulation.

${ }^{9}$ See Uchitelle (2010).

${ }^{10}$ See Lawson (2009).
} 
Indeed, during the crisis, the large failures of institutions occurred not among banks, but among non-bank financial conglomerates such as Bear Stearns, Lehman Brothers, Merrill Lynch and American International Group (AIG). In short, the financial crisis was the result of poor regulation of new intermediaries acting outside the traditional regulatory structure that existed before and after the GLBA. The GLBA did not deregulate the financial services industry beyond allowing for integration of institutions across product lines. As Wallison points out in the next chapter, without the GLBA, the failures of investment banks and large thrift institutions would not have been so easily resolved and the spillover to all financial institutions and the economy would have been severe.

The notion that the financial crisis was a banking crisis has been fostered by the political posturing of both the Bush and Obama administrations, led by the adoption and implementation of TARP. The TARP program began by forcing banks and a few nonbank financial institutions to accept government funds without evidence that they were confronting any meaningful liquidity or solvency problems. Most of the banks paid back these funds as soon as they were allowed. While TARP had authority to spend up to $\$ 700$ billion, originally to acquire toxic assets of banks, less than $\$ 300$ billion was ever disbursed to banks, most of that was repaid with the next 18 months and in 2010 losses to TARP were projected to arise from funds provided to automobile producers and AIG, with little loss arising from funds advanced to commercial banks.

Another perspective on whether there was a GLBA or financial-crisis-induced failure of banks is that the failure experience of depository institutions (banks and thrifts) has not risen to the level of the last real crisis, the savings and loan (S\&L) crisis of the late 1980s and early 1990s. In a new broad historical review of financial crises, Reinhart and Rogoff (2009) refer to the S\&L crisis as a "bank-centered financial crisis" and they include it in their comparison of the subprime crisis to such crises. It must be noted that they use the term "milder," and not their terms "severe" or "systemic," in referring to the S\&L crisis and they conclude that the subprime crisis was worse than other banking crises in advanced countries or in the five crises that they call the "Big Five," "severe," and "systemic," crises. Certainly this suggests that the subprime crisis was the worst since at least Great Depression, but one natural indicator that Reinhart and Rogoff do not review, the number of bank failures, suggests otherwise. In 2008-09 there were 135 failures (there were only three in 2007, the first year of the crisis), and it is likely that there will be 170-200 failures in 2010. It is possible that, in 2010, the number of failures will reach or surpass the previous high of 179 in 1992, which came toward the end of the S\&L crisis. But a total of 300-350 failures for 2008-2010 pales in comparison with the three to four times larger number of failures in the worst three years of the $S \& L$ crisis (1989-1991), or the six times larger number of failures during the worst five years of the earlier crisis, 1808 in 1987-92. For the full 13-year period of elevated bank failures from 1981-93, there were 2,335 failures, about seven times as many as are likely in and following the subprime/financial crisis. At least for this indicator of banking crisis, the recent mortgage and financial crisis is hugely dwarfed by the so-called mild S\&L bankcentered financial crisis. 
A supporting view is offered by Bullard (2010), who argues that commercial banks, especially the smaller community banks, did not cause the crisis and do not need to be reregulated. He points out that 20 financial firms made up 80 percent of the assets of the Standard and Poor's 500 at the end of 2007. Only one third of the assets of these financial firms were controlled by bank holding companies, regulated by the Fed, while two thirds were non-bank financial firms, which are not in the bank regulatory system and not under the authority of the Fed. In his view, there were runs on the shadow banking system and these and the non-bank financial firms caused the crisis. He does not recognize that the Fed did have regulatory control over the holding companies, though he is correct that they did not have authority over non-bank financial firms.

Dodd-Frank provides more authority for the Fed and FDIC to close bank holding companies and other financial firms, but it is not likely that this will be the end of "too big to fail" (TBTF) despite claims that it will. The experience in the recent crisis extended the notion of TBTF to non-banks and even to non-financial firms, such as auto companies. Improved discretionary ability to close banks and bank holding companies was unnecessary and expanded discretionary control to close other financial and nonfinancial companies is not likely to be used in the event of another crisis. The only new power is the ability to use a discretionary threat to private sector firms that is likely to be abused in ways that are wholly unrelated to a real financial crisis. Fortunately, this congressional overreach is unlikely to survive future judicial challenge.

\section{The Profitability Perspective}

How did the GLBA impact U.S. banks' overall profitability? Despite gains in stock prices, there is no conclusive evidence that profitability or productivity rose for the banking industry as a whole. From an asset growth perspective, however, total assets of all banks grew at an 8.1 percent annual rate from 1999 to 2008, much faster than the gross domestic product (GDP) (4.9\%). Assets at the nation's four largest holding companies (Citigroup, JP Morgan Chase, Bank of America and Wells Fargo) grew more than twice as fast, however, expanding at a rate of 16.6 percent, more than three times as fast as the economy's GDP. The rest of the banking industry grew a little more slowly than the overall economy, with assets expanding at a 4 percent rate.

Certainly, the GLBA appears to have helped create jobs in the financial services sector. Prior to the GLBA (1987-99), employment in the financial services sector grew more slowly than overall employment, reflecting stagnation within the industry. However, from 1999 to 2007, financial services employment outpaced overall employment, reflecting the improving performance of the financial sector.

An increased level of competition within the banking sector is also indicated by the decline in net interest margins. From 1984 to 1999, the average net interest margin of all commercial banks was 4.17 percent. This number declined sharply (54 basis points) after the GLBA, averaging 3.63 percent from 1999 through the second quarter of 2009. The transformation of banking is reflected in a sharp shift in the importance of traditional financial intermediation (borrowing and lending) toward more fee income from services such as insurance and security sales, origination fees and service fees for overdrafts, 
loans of credit and other services. From 1969 to 1986, the share of interest income in total commercial bank income was about 90 percent. As the GLBA removed walls separating banks, insurance and securities firms, the share of interest income fell to 72 percent in 1999 and to 64 percent in 2003. Since then, the share rose to 73 percent in 2008 as traditional banking has reasserted its importance.

Senator Gramm laid out a market test of the future success of the GLBA:

The test that I believe we should use - the test I will use, the test I hope people looking at this bill years in the future will use - is, 'Did it produce a greater diversity of products and services for American consumers? Were those products better? And did they sell at a lower price?' I think if the answer to those three questions is yes, then this bill will have succeeded. ${ }^{11}$

According to the evidence above, the GLBA was a success, especially for the largest banks. On the other hand, Gramm's ultimate test of its success is its survival, though his explanation has come under a cloud of doubt, at least temporarily, because of the mortgage and financial crisis. Gramm argued,

Ultimately, the final judge of the bill is history. Ultimately, as you look at the bill, you have to ask yourself, 'Will people in the future be trying to repeal it, as we are here today trying to repeal - and hopefully repealing - Glass-Steagall?' I think the answer will be no. I think it will be no because we are doing something very different from Glass-Steagall. Glass-Steagall, in the midst of the Great Depression, thought government was the answer. In this period of economic growth and prosperity, we believe freedom is the answer. ${ }^{12}$

The GLBA survived the assault of leading intellectual and political critics in the United States and the United Kingdom, at least in their post-crisis reform efforts.

\section{What about "Wallet Share"?}

An early concern upon passage of the GLBA was that financial behemoths would take over the financial services industry. By 2009, only about 600 mostly small local and regional financial holding companies exist to facilitate cross-sector product availability. There is some question whether even this small number really provides full service product availability. The expansion of new products and services allowed by the GLBA has not resulted in increased products per household within institutions. Banks did not lure large numbers of customers away from insurance firms, nor did insurance companies lure significant numbers of customers away from traditional banks. As a result, the GLBA has not resulted in a meaningful diversification of product shares within individual firms.

The GLBA may have helped foster customer retention. While customers appear to have a preference for doing business with specialists across the product spectrum, customers who have concentrated their buying across banking, insurance or securities within a

\footnotetext{
${ }^{11}$ See Simpson (2009).
}

${ }^{12}$ See Simpson (2009). 
single holding company are likely to be more loyal, and less likely to flee when they encounter a more attractive offer for a single product.

\section{Examining the Legacy}

Like most regulation, the GLBA has been both condoned and vilified, particularly in the context of the economic meltdown. However, the GLBA appears to have been a significant factor in supporting the vigor and health of U.S. banks by enabling them to deliver products and services that enhance competition and deliver the services consumers demand. Notably, the solvency of the nation's banks has improved dramatically in the past decade. Banks reached an historical peak in their ratio of capital to assets, or lowest leverage ratio, in mid 2008 - about the same time the financial meltdown was capturing national headlines. Over the past 10 years, the GLBA has played a role in the growth of the U.S. banking industry, making it more internationally competitive and more resilient to economic and financial shocks. Despite its critics, the GLBA has increased innovation as well as enhanced the convenience of financial services for both consumers and businesses. The GLBA broke down restrictive barriers brought about during the Great Depression. Despite the criticisms of the GLBA during the financial crisis and early stages of the legislative debate for financial regulatory reform, no effort to repeal the GLBA surfaced.

In the development of the GLBA, primary concerns focused on consumer protection and privacy issues. Today, systemic risk, subprime credit and mortgage credit crisis issues introduce new concerns. Dodd-Frank created a new Consumer Financial Protection Bureau, housed within the Federal Reserve, but independent of them. The new bureau will have power to write regulation, examine and enforce it for banks, thrifts and credit unions with assets over $\$ 10$ billion, mortgage-related businesses, payday lenders and certain non-bank financial firms, though auto dealers are explicitly exempt. Dodd-Frank did not retire or consolidate any of the existing financial regulatory bodies, however, except for merging the federal chartering and regulation of thrifts with that of banks within the Office of the Comptroller of the Currency (OCC) in the U.S. Department of Treasury. This transfers consumer protection rules for thrifts to oversight by the OCC, as well as the new bureau. Thus, Dodd-Frank continues the pursuit of stronger consumer protection regulation and in this regard it touches on one area that some analysts believed contributed to the mortgage and financial crisis of 2007-09, the concern to protect consumers from predatory lending. There is no evidence that predatory lending contributed to the mortgage crisis, however, as predation with unsustainable mortgage lending ran from borrowers to lenders and to mortgage-backed asset investors.

As new regulatory structures are considered, these "new" questions will need to be addressed. The subprime crisis was largely due to credit extensions among mortgage bankers and thrift institutions. Additionally, the creation of complex new products such as mortgage-backed securities, collateralized mortgage obligations, collateralized debt obligations, auction rate securities and credit default swaps were developed and marketed outside traditional regulatory structures. These gaps will certainly be considered in any new system of regulation and oversight. 
On the other hand, some analysts have noted that, without the GLBA, the ability of the financial system to insulate investors from larger losses and instability would have been more restricted [see Wallison (2009), for example]. Some banks that had extensive investment banking operations have experienced relatively large losses (Citigroup, Bank of America); but, it was the largely non-bank affiliated Bear Stearns and Lehman Brothers whose failure is most closely linked to the financial crisis.

Looking forward, new regulation may or may not affect the GLBA. As noted above, Dodd-Frank did not alter the financial structure or other aspects of the GLBA very much. Dodd-Frank left the product offerings of financial institutions largely intact. The exceptions are that banks will no longer be able to undertake proprietary trading and their offerings of hedge fund services and private equity services will each be limited to 3 percent of total assets. Paul Volcker, former chairman of the Fed and adviser to President Obama, had recommended that all three of these activities be prohibited in the new legislation. Instead, only proprietary trading was prohibited and the other activities were limited. Of these three activities, only private equity had been expanded for U.S. banks in the GLBA.

In 2008, Secretary of Treasury Henry Paulson's Blueprint [(see U.S. Treasury (2008)] called for a move to regulation by risk type rather than function, referred to as a move from functional regulation to objectives-based regulation. Essentially, the regulatory structure had remained unchanged by the GLBA, regulating various financial firms along product lines, despite the possibility of merging products lines under the GLBA. These regulatory "silos," regulating according to types of products rather than types of risk were a target of the Paulson Blueprint. This proposal did not survive into the Obama proposal of 2009 [see U.S. Treasury (2009)], though there was otherwise broad agreement in the two regulatory reform proposals and indeed, Dodd-Frank incorporated many of the proposals in both documents. For example, Dodd-Frank consolidated the Office of Thrift Supervision in the Office of the Comptroller of Currency and ended the thrift charter, as both sets of proposals had agreed earlier. It also set up a Federal Office of National Insurance to serve as a national center for insurance information and federal policy, as well as a coordinator for federal insurance policy in international policy coordination. Perhaps most importantly, it established a separate and independent consumer protection regulator, the Consumer Financial Protection Bureau, as both earlier proposals had recommended and, most notably, the most significant aspect of the Paulson plan's objectives-based regulation that carried through to the new legislation.

Another component of the objectives-based regulatory structure proposed in the Blueprint called for a regulator of financial stability. Dodd-Frank includes a Financial Stability Oversight Council composed of all the various existing regulators and chaired by the Secretary of Treasury. It does not abolish the Fed's role in monitoring and controlling financial stability, however, as envisioned by the Blueprint. Creation of the Consumer Financial Protection Bureau and the Financial Stability Oversight Council may be only the first steps in moving toward the new structure envisioned in the Blueprint. However, the Blueprint's notion of having a single regulator for prudential regulation suffered a major setback in its omission from the Obama proposals, its omission from Dodd-Frank, 
and from the abolition of the Financial Services Authority, the world's leading example of an objectives-based regulator, in favor of moving prudential regulation back under the Bank of England, the central bank and principal institution for financial stability.

Despite the criticism that the GLBA contributed to the financial crisis, the only two large investment banks that were not previously part of financial holding companies (Morgan Stanley and Goldman Sachs) became financial holding companies in order to improve their strength during the crisis. Smaller investment banks that do not also function as banks may remain so over the next decade if they survive as independent investment banks. Several large financial holding companies have emerged over the past ten years including JP Morgan Chase, Bank of America, Citigroup and Wells Fargo. There are about seven large foreign universal banks that rely primarily on deposit taking but also have securities. It is likely that efforts to expand product offerings, which have continued over more than three decades, will continue, even among the large financial holding companies. Moreover, some midsize and small banks will continue to offer a broad portfolio of financial products and services. Whether financial holding companies will remain so in the future will depend in part on how new regulations under Dodd-Frank play out. Since all financial institutions are now subject to the Fed's new financial oversight and the new law gives significance to the Fed's notion of financial firms, broadly conceived, being "too interdependent to fail," there will be little advantage to being a bank, a bank holding or a financial holding company and only more regular and pervasive costs associated with the tighter oversight of bank and bank holding companies. While the Fed could intervene, it is likely that as time makes the financial crisis and passage of Dodd-Frank more distant, some large financial firms that specialize in non-bank activity may give up their status as a financial holding company with a commercial bank affiliate. 


\section{References}

Barth, James R., Gerard Caprio, Jr. and Ross Levine (2006). Rethinking Bank Regulation: Till Angels Govern. New York: Cambridge University Press.

Benston, George (2000). "Consumer Protection as Justification for Regulating FinancialServices Firms and Products," Journal of Financial Services Research 17, 277-301.

Bullard, James (2010). "Containing Risk in the New Global Financial Landscape," $19^{\text {th }}$ Annual Hyman P. Minsky Conference on the State of the U.S. and World Economies, New York, April 10, http://research.stlouisfed.org/econ/bullard/BullardLevyMinskyFinalApril15.pdf .

French, Kenneth R. et al (2010). The Squam Lake Report. Princeton: Princeton University Press.

Kaufman, Henry (2010). The Road to Financial Reformation: Warnings, Consequences, Reforms. Hoboken: John Wiley and Sons, Inc.

Krugman, Paul (2009). “The Gramm Connection,” personal blog. March 29.

Lawson, Nigel (2009). “The Future of Capitalism,” Financial Times, May 12.

Paletta, Damian and Kara Scannell (2009). "The Question for Those Fixing the Financial Mess," Wall Street Journal, March 10.

Reinhart, Carmen M. and Kenneth S. Rogoff (2009). This Time is Different. Princeton: Princeton University Press.

Simpson, Andrew G. (2009). “Would Gramm Leach Bliley Pass Senator Gramm’s Own Test?' Insurance Journal, April 4. www.insurancejournal.com/news/national/2009/04/20/99770.htm

Uchitelle, Louis (2010). "Volcker Pushes for Reform, Regretting Past Silence," New York Times, July 9.

U.S. Department of the Treasury (2009). Financial Regulatory Reform: A New Foundation: Rebuilding Financial Supervision and Regulation, June 17. http://www.financialstability.gov/docs/regs/FinalReport_web.pdf.

U.S. Department of the Treasury (2008). Blueprint for a Modernized Financial Regulatory Structure, March 31. http://www.ustreas.gov/press/releases/reports/Blueprint.pdf

VanHoose, David (2010). The Industrial Organization of Banking, Berlin: SpringerVerlag. 